\section{ИМПУЛЬСНЫЙ ТЕРАГЕРЦЕВЫЙ СПЕКТРОМЕТР ИТС-1}

\author{
И. А. Цибизов, Г.И. Кропотов, к. ф.- м. н., \\ ООО "ТИДЕКС", www.tydex.ru, Санкm-Петербург, \\ Россия
}

\begin{abstract}
Импульсный терагерцевый спектрометр ИТС-1 прибор для терагерцевой спектроскопии во временной области (Terahertz Time-Domain Spectroscopy). Для генерации ТГц-излучения в ИТС-1 используется метод оптического выпрямления фемтосекундных импульсов (optical rectification). Средняя выходная мощность генерируемого ТГц-излучения 300 мкВт, коэффициент преобразования сигнала из оптического в ТГц-диапазон 10-4. Прибор обладает достаточно гибкой оптической схемой, имеет многофункциональное программное обеспечение. В статье приведены результаты испытаний.
\end{abstract}

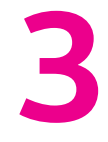

а последние несколько лет научному сообществу стали доступны коммерческие терагерцевые (ТГц) системы спектроскопии во временной области (THz-TDS). Эти системы отличаются между собой вариантами компоновки и различными параметрами, но их всех объединяет относительно небольшой уровень средней выходной мощности ТГц-излучения.

В 2013 году в компании "ТИДЕКС" было принято решение о начале разработки собственного ТГц-спектрометра. Нами была составлена и подана заявка на конкурс, объявленный $\Phi о н-^{-}$ дом содействия инновациям. Заявка была поддержана, и в октябре 2013 года мы начали разработку Импульсного ТГц-Спектрометра ИТС-1. В качестве консультантов и наших партнеров выступили сотрудники Лаборатории экстремальных световых полей Нижегородского государ ственного университета им. Н.И. Лобачевского. После ряда обсуждений было принято решение, что для генерации ТГц-излучения в ИТС-1 будет использоваться эффект оптического выпрямления фемтосекундных лазерных импульсов в условиях черенковского фазового синхронизма [1]. Благодаря использованию мощного лазера накачки и вышеописанного метода генерации планировалось получить высокий коэффициент преобразования оптического излучения в терагерцевое, что в свою очередь позволило

\section{PULSED TERAHERTZ SPECTROMETER PTS-1}

\author{
I. A. Tzibizov, G. I. Kropotov, Cand.Sc. (Phys-Math.), \\ TYDEX, www.tydex.ru, St. Petersburg, Russia
}

Pulsed terahertz spectrometer ITS-1 - a device for Terahertz Time-Domain Spectroscopy - is presented. The method of optical rectification of femtosecond pulses is implemented to generate $\mathrm{THz}$ radiation in ITS-1. The average output power of the generated $\mathrm{THz}$ radiation is $300 \mu \mathrm{W}$, the conversion coefficient of the signal from the optical to the $\mathrm{THz}$ range is $10^{-4}$. The device has a sufficiently flexible optical scheme and multifunctional software. The article presents the results of the tests.

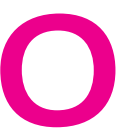

ff-the-shelf terahertz time domain spectroscopy systems (THz-TDS) became available to the scientific community over the last few years. Although such systems differ in layout and various parameters, all of them exhibit relatively low average output power of $\mathrm{THz}$ radiation.

In 2013 Tydex decided to design its own $\mathrm{THz}$ spectrometer. We applied to a competition held by the Foundation for Assistance to Small Innovative Enterprises in Science and Technology. Our application was funded, and thus we commenced the development of the Pulsed THz Spectrometer PTS-1 in October 2013. We enlisted employees from the Extreme Light Sources and Application (ELSA) laboratory of N.I. Lobachevsky State University of Nizhny Novgorod as our experts and partners. After some discussion, we decided that PTS-1 would generate $\mathrm{THz}$ radiation by means of optical rectification of femtosecond laser pulses under the condition of Cherenkov phase matching[1]. High-power pumping laser and the aforementioned generation method would ensure high optical-to-terahertz conversion ratio, thus providing high average output power of $\mathrm{THz}$ radiation.

By April 2015 we finally achieved our objectives and developed a breadboard model of a $\mathrm{THz}$ spectrometer that met all the key design specifications. We spent the next two years getting the system ready for serial production, and developing software to control the entire integrated set. All development and preproduction activities were complete by the end of 2017, and we unveiled the first commercial PTS-1 model.

A pulsed terahertz spectrometer by Tydex LLC is an integrated solution for broadband terahertz time- 
бы добиться высокого уровня средней мощности ТГц-излучения.

В апреле 2015 года мы успешно справились с поставленными задачами и разработали макетный образец ТГц-спектрометра, в котором удалось реализовать все ключевые характеристики. Следующие два года ушли на подготовку к серийному производству системы, а также на разработку программного обеспечения (ПО) для управления всем комплексом. В итоге в конце 2017 года все работы по разработке и подготовке к серийному производству спектрометра были завершены, и мы представили первый коммерчески доступный образец ИТС-1.

Импульсный терагерцевый спектрометр производства ООО "ТИДЕКС" - это комплексное решение для широкополосной терагерцевой спектроскопии во временной области. В состав ИТС-1 входит (рис. 1):

- твердотельный фемтосекундный лазер;

- электрооптический детектор (ЭОД) импульсного ТГц-излучения;

- все оптомеханические компоненты для оптического и ТГц-пути;

- линия задержки;

- управляющие электронные блоки оптической линии задержки, оптико-механического модулятора и лазера;

- ПК с установленным ПО TydexLN.

Принципиальная оптическая схема иТс-1 представлена на рис. 2. Излучение иттербиевого твердотельного фемтосекундного лазера TeMa-1050/100, произведенного нашими партнерами ООО "Авеста", разделяется на два пучка: пучок накачки и зондирующий (пробный) пучок. Более мощный пучок накачки используется для генерации ТГц-импульса. Генерация происходит при воздействии лазерного импульса накачки на кристалл 1\% MgO:LiNbO 3 . Зондирующий пучок используется для детектирования ТГц-импульса. В ИТС-1 для детектирования ТГц-излучения используется электрооптический детектор ЭОД-БИК производства ОоО "ТИДЕКС". Детектирование происходит за счет изменения поляризации зондирующего импульса в присутствии ТГц-импульса.

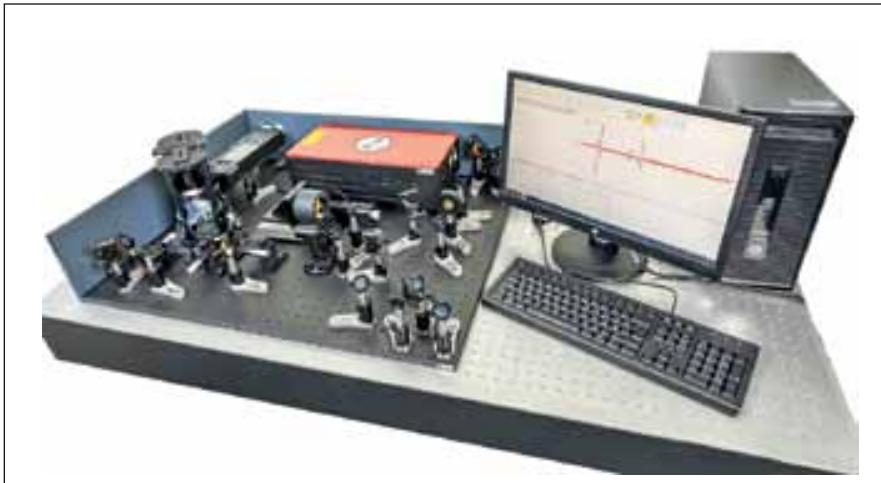

Puc. 1. Импульсный терагерцевый спектрометр ИТС-1 Fig. 1. External view of the PTS-1

domain spectroscopy. The PTS-1 includes the following (Fig. 1):

- Solid-state femtosecond laser;

- Electro-optical detector of pulsed THz radiation;

- All optomechanical components for the optical and $\mathrm{THz}$ path;

- Delay line;

- Electronic control units for the optical delay line, optomechanical modulator and laser;

- $\quad$ PC with pre-installed TydexLN software.

General optical layout of the PTS-1 is shown in Fig.2. Radiation from an ytterbium solid-state femtosecond laser TeMa-1050/100, which is manufactured by our partners from Avesta LLC, is split into two beams, a pumping beam and a probe beam. A more powerful pumping beam is used to generate $\mathrm{THz}$ pulses. The generation occurs when the pumping pulse interacts with $1 \% \mathrm{MgO}: \mathrm{LiNbO}_{3}$ crystal. The probe beam is

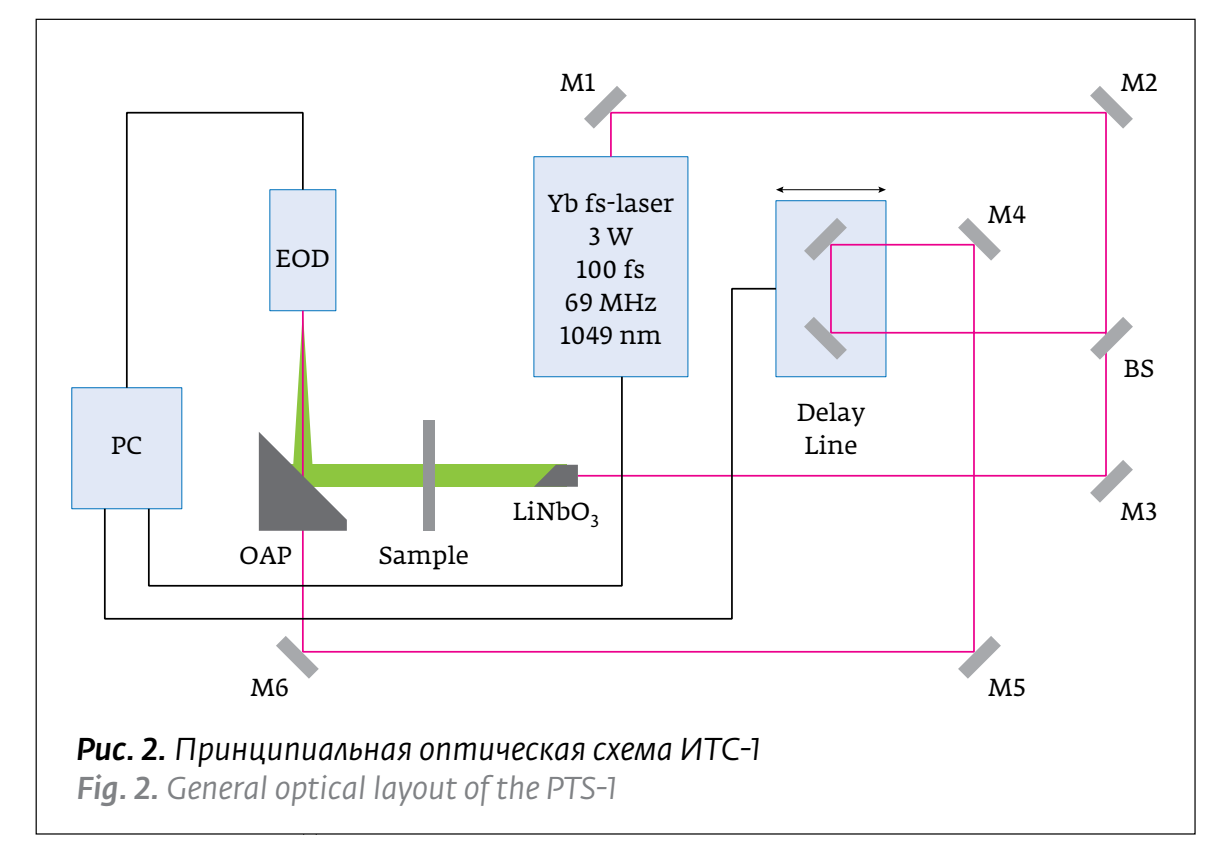


Общим для всех механизмов является коге рентность оптических импульсов (импульса накачки и зондирующего импульса) и ТГцимпульса. Под когерентностью в данном случае понимается связь фазы ТГц-импульса с интенсивностью оптического импульса. Эта связь постоянна во времени и выдерживается с высо кой точностью. Флуктуации частоты повторения лазерных импульсов или механические вибрации одинаковы как для ТГц-импульса, так и для импульса накачки, поэтому они не нарушают этой когерентности. Импульс накачки и зонди рующий импульс являются репликами одного и того же импульса и потому также сохраняют когерентность. Таким образом, ТГц- и зондиру ющий импульсы оказываются привязаны друг к другу по фазе. Благодаря такой привязке, зондирующий импульс взаимодействует в детекторе с одним и тем же участком ТГц-импульса. Длительность зондирующего импульса составляет обычно десятки фемтосекунд, что много меньше периода ТГц-импульса (единицы пикосекунд). Поэтому можно считать, что зондирующий импульс взаимодействует с некоторым квазипостоянным полем. Внося временную задержку зондирующего импульса по отношению к импульсу накачки (и связанному с ним ТГц-импульсу), можно подбирать относительное время прихода в детектор зондирующего и ТГц-импульсов и детектировать разные участки импульса с временным разрешением, соответствующим величине длительности зондирующего импульса. Сканируя интервал временных задержек с помощью механической линии задержки, можно получать волновую форму ТГц-импульса.

Преобразование Фурье от волновой формы позволяет получить спектр ТГЦ-импульса. Для того чтобы, например, получить спектр пропускания некоторого образца, необходимо выполнить ряд действий: сначала измерить спектр без образца, затем получить спектр с образцом, а после этих процедур поделить последний спектр на первый. Таким образом, мы получим спектр пропускания образца.

Как уже отмечалось выше, для генерации ТГц-излучения в ИТС-1 было принято решение использовать эффект оптического выпрямления фемтосекундных лазерных импульсов. Эффект оптического выпрямления состоит в возник новении в среде при прохождении через нее интенсивного оптического импульса нелинейной поляризации, повторяющей форму огибающей оптического импульса. used to detect the $\mathrm{THz}$ pulse. To detect the $\mathrm{THz}$ radiation, the PTS-1 uses a NIR electro-optical detector manufactured by Tydex. The detection is based on change of polarization of the probe pulse in the presence of $\mathrm{THz}$ pulse.

The common feature of all mechanisms is the coherence of optical pulses (both pumping and probe) and the $\mathrm{THz}$ pulse. Here the coherence means the correspondence between $\mathrm{THz}$ pulse phase and optical pulse intensity. This correspondence is constant in time to a high degree of precision. Fluctuations of laser pulse repetition rate and mechanical vibrations are the same for $\mathrm{THz}$ pulse and pumping pulse, and do not affect the coherence. Since pumping pulse and probe pulse replicate the same basic pulse, they are coherent as well. Thus, $\mathrm{THz}$ pulse and probe pulse are phase-matched. Due to this matching, the probe pulse always interacts with the same part of the $\mathrm{THz}$ pulse within the detector. Probe pulse duration is usually measured in tens of femtoseconds, which is much less than $\mathrm{THz}$ pulse period (several picoseconds). Thus, it can be viewed as interaction between the probe pulse and some quasi-constant field. By introducing a time delay between pumping pulse (which is tied to the THz pulse) and probe pulse, one can vary the relative time of arrival of probe and $\mathrm{THz}$ pulses to the detector. This method allows detecting various regions of the pulse. Temporal resolution corresponds to the duration of the probe pulse. By scanning along the time delay range using a mechanical delay line, $\mathrm{THz}$ pulse waveform can be reconstructed.

Fourier transformation of the waveform gives the spectrum of the $\mathrm{THz}$ pulse. For example, to measure the transmission spectrum of a sample, the pulse spectra with and without the sample must be measured. Then divide one by the other. The result will be the transmission spectrum of the sample.

As we mentioned above, it was decided to achieve $\mathrm{THz}$ radiation generation in the PTS-1 by means of optical rectification of femtosecond laser pulses. The optical rectification phenomenon involves formation of nonlinear polarization in a medium exposed to a high-intensity optical pulse. Said polarization follows the envelope shape of the optical pulse.

When radiation propagates through an optical medium with second-order nonlinear susceptibility $\chi^{(2)}$, nonzero nonlinear polarization occurs (is induced by electrical field of the radiation) and travels along with the radiation. Whilst at low radiation intensities the nonlinear polarization is proportional to the electric field strength, nonlinear terms become significant at high optical intensities - for example, 
Когда излучение распространяется сквозь оптическую среду с нелинейной восприимчивостью второго порядка $\chi^{(2)}$, появляющаяся в среде и распространяющаяся вместе с излучением нелинейная поляризация (электрическая поляризация среды, наведенная электрическим полем излучения) имеет ненулевое значение. В то время как при малых интенсивностях излучения нелинейная поляризация пропорциональна напряженности электрического поля, нелинейные вклады становятся важными при высоких оптических интенсивностях, полученных, например, с помощью лазерных импульсов. Лазерное излучение генерирует нелинейную поляризационную волну с более низкой частотой, которая распространяется с фазовой скоростью V, равной групповой скорости оптического импульса (рис. 3). Нелинейная поляризационная волна излучает другое оптическое поле на этой частоте.

Для лазерного излучения с постоянной или слабо меняющейся мощностью возникающая квазипостоянная (низкочастотная) нелинейная поляризация обычно не имеет заметного эффекта. Однако в случае ультракоротких импульсов сила квазипостоянной компоненты быстро возрастает и так же быстро падает, что приводит к излучению электромагнитного импульса с широким спектром частот (примерно в диапазоне от нулевой частоты до некоторого максимального значения, где общая полоса пропускания определяется инверсией длительности импульса). Например, для оптического импульса с длительностью 100 фемтосекунд результирующий импульс излучения имеет частотные составляющие, выходящие за пределы 10 ТГц.

В кристаллах с высокими значениями элементов тензора нелинейной восприимчивости второго порядка $\chi^{(2)}$, мгновенное значение нелинейной поляризации можно представить в следующем виде:

$$
P^{N L}(t, r)=\chi^{(2)} E(t, r) E(t, r)
$$

где $\mathrm{E}(\mathrm{t}, \mathrm{r})$ - мгновенная величина электрического поля лазерного импульса.

В зависимости от дисперсионных свойств электрооптического кристалла излучение ТГцволн может происходить за счет различных механизмов.

Если скорость источника (нелинейная поляризация в нелинейном кристалле) совпадает с фазовой скоростью ТГц-волны на определенной частоте, то реализуется механизм попутного

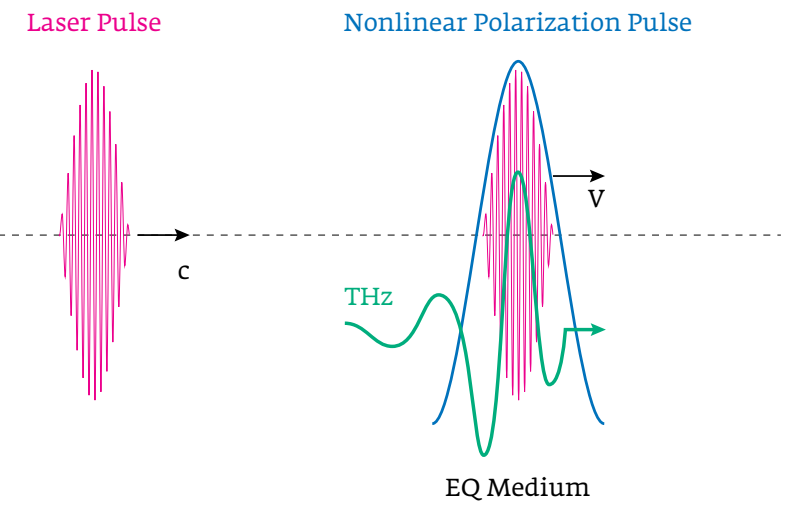

Puc. 3. Onтическое выпрямление

Fig. 3. Optical rectification

achieved by a laser pulse. Laser pulse generates a lower-frequency nonlinear polarization wave that propagates with phase velocity $\mathrm{V}$ equal to the group velocity of the optical pulse (Fig. 3). Nonlinear polarization wave radiates own optical field at aforementioned frequency.

For laser beams with approximately constant or slowly varying optical power, the quasi-DC (low frequency) nonlinear polarization is usually negligible. In case of ultra-short pulses, however, the strength of the quasi-DC component rises and falls off rapidly, and that leads to emission of an electromagnetic single-cycle pulse with a wide frequency spectrum, ranging roughly from zero frequency to some maximum value, where the overall bandwidth is essentially determined by the inverse of the pulse duration. For an optical pulse with a duration of 100 femtoseconds, for example, the resulting radiation pulse has frequency components going beyond $10 \mathrm{THz}$.

In crystals with significant second-order nonlinear susceptibility tensor components $\chi^{(2)}$, instantaneous nonlinear polarization value is given by:

$$
P^{N L}(t, r)=\chi^{(2)} E(t, r) E(t, r),
$$

where $E(t, r)$ is the instantaneous electrical field strength of the laser pulse.

Depending on dispersive properties of the electrooptical crystal, $\mathrm{THz}$ wave generation can occur by a variety of mechanisms.

When the velocity of the source (i.e. nonlinear polarization in a nonlinear crystal) coincides with phase velocity of a $\mathrm{THz}$ wave at specific frequency, collinear phase matching occurs (see Fig. 4 a). When the source propagates faster than the $\mathrm{THz}$ wave, 
синхронизма (рис. 4а). Если источник движется со скоростью, большей чем скорость ТГц-волны, то может реализовываться другой механизм синхронизованного возбуждения: волна, распространяющаяся под углом $\theta$ к скорости источника $\mathrm{V}$, также находится в фазе с источником - явление черенковского синхронизма (рис. 4 b).

При фокусировании лазерного импульса до поперечного размера порядка или меньше длины ТГц-волны становится эффективным черенковский механизм генерации - синхронизованное возбуждение ТГц-волн, распространяющихся под углом к лазерному лучу и образующих черенковский конус [2].

Генерируемое ИТС-1 импульсное ТГцизлучения регистрируется методом электрооптического стробирования, при помощи ЭОД-БИК. Электрооптическое стробирование основывается на эффекте Поккельса, который заключается в изменении показателя преломления среды в оптическом диапазоне в присутствии внешнего электрического поля (в данном случае поля ТГц-импульса). В методе электрооптического стробирования поле ТГц-импульса изменяет ориентацию эллипсоида показателей преломления электрооптического кристалла (кристалл становится двулучепреломляющим). При прохождении через электрооптический кристалл (в ЭОД-БИК используется кристалл $\mathrm{ZnTe}$ ) линейно поляризованного зондирующего импульса совместно с ТГц-импульсом, поляризация зондирующего импульса становится эллиптической в результате различного набега фаз для обык новенной и необыкновенной волны. Величина эллиптичности (пропорциональная величине ТГц-поля) может быть зарегистрирована с помощью поляризационного анализатора. В ЭОДБИК в качестве поляризационного анализатора используется четверть волновая пластинка и призма Волластона. Далее два пучка разных поляризаций, полученные с помощью поляризационного анализатора, детектируются двумя фотодиодами (рис. 5). Регистрация разностного сигнала с диодов позволяет подавить шумы лазера. Для увеличения чувствительности схемы пучок накачки модулируется с помощью механического прерывателя, и с помощью синхронного усилителя, встроенного в ЭОД-БИК, детектиру ется вызванная ТГц-импульсом модуляция поля ризации пробного пучка.

Как выше было сказано, для получения черенковского конуса терагерцевых волн оптический импульс должен фокусироваться на

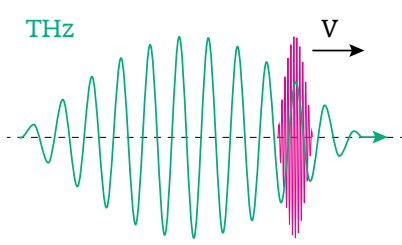

Laser Pulse

a)

Puc. 4. Механизмы генерации ТГи-волн: $a$ - попутный синхронизм; $b$ - черенковский синхронизм

Fig. 4. Mechanisms of THz wave generation: a - collinear matching, b-Cherenkov matching

another case of phase-matched excitation can occur. The wave propagating at angle $\theta$ to the source velocity vector $\mathrm{V}$ is also phase-matched to the source. It is known as Cherenkov phase matching (see Fig.4 b).

When the laser beam is focused to a crosswise size about or less than $\mathrm{THz}$ wave length, Cherenkov generation becomes efficient. Phase-matched $\mathrm{THz}$ waves are generated that propagate at an angle to the laser beam and form the Cherenkov cone [2].

The $\mathrm{THz}$ radiation pulses generated by the PTS- 1 are detected by means of electro-optical sampling using a NIR EOD. The electro-optical sampling utilizes the Pockels effect, change of the optical refractive index of the medium induced by an external electric field (in this case, the field of the $\mathrm{THz}$ pulse). In the electro-optical sampling method, the field of the $\mathrm{THz}$ pulse changes the orientation of the refractive index ellipsoid of the electro-optical crystal (the crystal becomes birefringent). The NIR EOD uses ZnTe electrooptical crystal. When a linearly polarized probe pulse propagates through the crystal along with $\mathrm{THz}$ pulse, is becomes elliptically polarized due to the phase difference between ordinary and extraordinary wave. The ellipticity is proportional to the $\mathrm{THz}$ field strength and can be detected with a polarization analyzer. The NIR EOD uses a quarter-wave plate and Wollaston prism as a polarization analyzer. Downstream of the

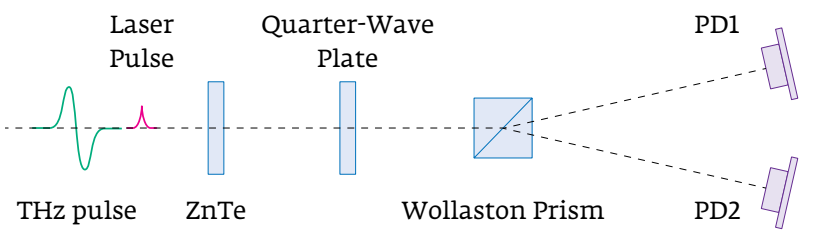

Puc. 5. Принципиальная схема ЭОД

Fig. 5. General layout of the EOD 
величину порядка или меньше длины терагерцевой волны. Для этой цели, излучение лазера накачки (средняя выходная мощность 3,14 Вт, центральная длина волны 1049 нм, длительность импульса 100 фс, частота повторения 69 МГц) было сфокусировано в $10 \times 10 \times 1$ мм $1 \%$ $\mathrm{MgO}: \mathrm{LiNbO}_{3}$ плоско-выпуклой линзой с фокусным расстоянием 75 мм (рис. 6). Фазовый синхронизм достигается между движущимся оптическим импульсом и плоской терагерцевой волной, распространяющейся под углом $\theta\left(40,5^{\circ}\right)$ к лазерному пучку. Чтобы преодолеть эффект возникновения полного внутреннего отражения ТГц-волн в кристалле $\mathrm{LiNbO}_{3}$, использовалась призма из HRFZ-Si [3]. Чтобы преодолеть высокое поглощение ТГц-излучения в $\mathrm{LiNbO}_{3}$, лазерный луч накачки был выровнен параллельно и вблизи границы $\mathrm{LiNbO}_{3}$-Si.

Генерируемое в спектрометре излучение регистрировалось двумя способами: методом электрооптического стробирования и методом детектирования с помощью детектора Голея. Волновая форма генерируемого ТГц-импульса, полученная методом электрического стробирования, приведена на рис. 7а. Спектр ТГЦимпульса, представляющий собой преобразование Фурье от волновой формы ТГц-импульса, представлен на рис. 7b. Средняя мощность ТГцизлучения была измерена с помощью калиброванного детектора Голея. Для такого измерения в пучок накачки помещался оптический прерыватель (частота модуляции составляла 20 Гц). Чтобы заблокировать любое нежелательное излучение (например лазерное излучение накачки), на входной апертуре детектора Голея

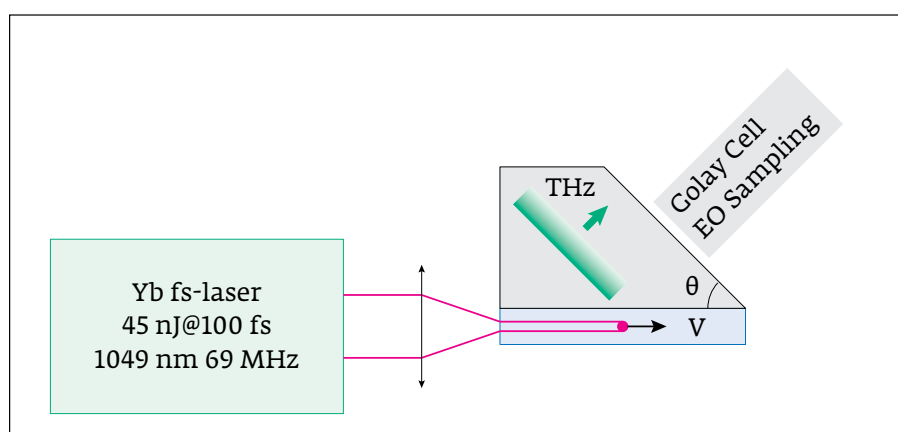

Puc. 6. Схема генерации и детектирования ТГи-излучения Fig. 6. THz radiation generation and detection setup

polarization analyzer, the two differently polarized beams are detected using two photodiodes (Fig.5). Detection of difference signal from two diodes allows to suppress laser noise. To increase the sensitivity of the setup, the pumping beam is modulated with a mechanical chopper. A lock-in amplifier built into the NIR EOD helps to detect polarization modulation of the probe beam induced by the $\mathrm{THz}$ pulse.

As it was already mentioned, to obtain Cherenkov cone of terahertz waves, optical pulse has to be focused to a crosswise size about or less than $\mathrm{THz}$ wave length. To achieve this, the radiation from the pumping laser (average output power $3.14 \mathrm{~W}$, center wavelength 1049 $\mathrm{nm}$, pulse duration $-100 \mathrm{fs}$, repetition rate $69 \mathrm{MHz}$ ) was focused into $10 \times 10 \times 1 \mathrm{~mm} 1 \% \mathrm{MgO}: \mathrm{LiNbO}_{3}$ crystal using a plano-convex lens with focal length $75 \mathrm{~mm}$ (Fig.6). Phase matching is achieved between moving optical pulse and flat terahertz wave propagating at angle $\theta\left(40.5^{\circ}\right)$ to the laser beam. To avoid total internal reflection of $\mathrm{THz}$ waves in the $\mathrm{LiNbO}_{3}$ crystal, a HRFZ-Si prism was used [3]. To overcome high 


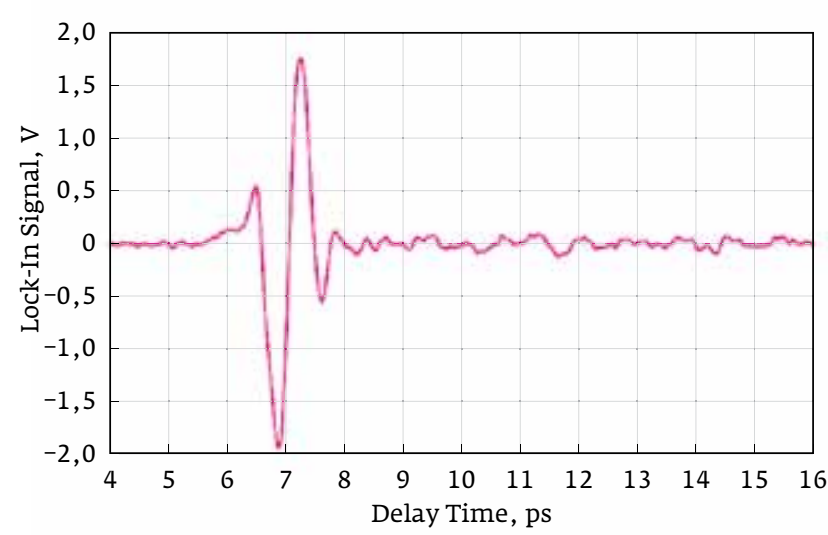

a)

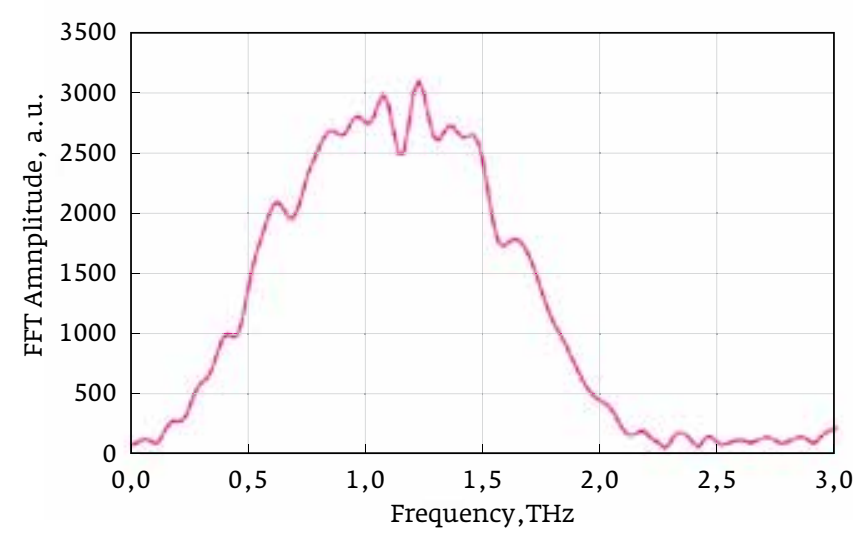

b)

Puc. 7. Генерируемый в спектрометре ТГц-импульс: $a$ - волновая форма ТГц-импульса; $b$ - спектр ТГЦ-импульса

Fig. 7. The radiation produced in the spectrometer: $a$-THz pulse waveform; $b$ - THz pulse spectrum

был установлен фильтр низких частот (ФНЧ) с частотой среза 10,9 ТГц. Амплитуда ТГцсигнала, измеренная на выходной поверхности кремниевой призмы, составила 5,15 В. Чувствительность детектора Голея при частоте модуляции 20 Гц составляет 24,5 кB/Вт. Мы оценили среднюю мощность излучения, принимая во внимание потери в ФНЧ $\left(\mathrm{T}_{\mathrm{LPF}}=70 \%\right)$. Оценка показала, что средняя мощность ТГц-излучения, генерируемого в ИТС-1, достигла значения около 300 мкВт.

В данной статье мы представили коммерчески доступный ТГц-спектроскопический комплекс ИТС-1 со средней выходной мощностью 300 мкВТ и коэффициентом преобразования оптического сигнала в терагерцевый $10^{-4}$. ИТС-1 идеально подходит для научных исследований, благодаря распространению излучения в свободном пространстве, обладанию достаточно гибкой оптической схемой и наличию многофункционального программного обеспечения.

Разработка была поддержана Фондом содействия инновациям (FASIE), контракт № 12234p / 23287.

\section{ЛИТЕРАТУРА}

1. Stevens T. E., Wahlstrand J. K., Kuhl J., Merlin R. Cherenkov Radiation at Speeds Below the Light Threshold: Phonon-Assisted Phase Matching // Science. Jan., 2001.Vol. 291, Iss. 5504, p. 627-630.

2. Hebling J., Almási G., Kozma I.Z. Velocity matching by pulse front tilting for large area THz-pulse generation // Optics Express, Oct., 2002, Vol. 10, No. 21, p. 1161-1166.

3. Bodrov S. B., Stepanov A. N., Bakunov M. I. et al. Highly efficient opticalto-terahertz conversion in a sandwich structure with $\mathrm{LiNbO}_{3}$ core // Optics Express, Feb., 2009, Vol. 17, No. 3, p. 1871-1879. absorption of $\mathrm{THz}$ radiation within $\mathrm{LiNbO}_{3}$ crystal, the pumping laser beam was aligned parallel and in close proximity to the $\mathrm{LiNbO}_{3}$-Si interface.

The radiation produced in the spectrometer was detected by two different means, by electrooptical sampling and with a Golay cell. Waveform of the generated $\mathrm{THz}$ pulse, as measured by electrooptical sampling, is shown in Fig.7a. THz pulse spectrum obtained by Fourier transformation of the $\mathrm{THz}$ pulse waveform is shown in Fig.7b. Average $\mathrm{THz}$ radiation power was measured by means of a calibrated Golay cell. For this purpose, the pumping beam was modulated by an mechanical chopper (modulation frequency was $20 \mathrm{~Hz}$ ). To suppress any unwanted radiation (such as pumping laser light), the entrance aperture of the Golay detector was equipped with a low-pass filter (LPF) with cutoff frequency $10.9 \mathrm{THz}$. THz signal amplitude measured at the output surface of the silicon prism was $5.15 \mathrm{~V}$. Golay cell sensitivity at $20 \mathrm{~Hz}$ modulation frequency is $24.5 \mathrm{kV} / \mathrm{W}$. Taking into account the LPF losses $\left(\mathrm{T}_{\mathrm{LPF}}=70 \%\right)$, we've achieved $-300 \mu \mathrm{W}$ average $\mathrm{THz}$ radiation power generated by the PTS -1 .

In this paper we have presented a commercial off-the-shelf THz spectroscopy set PTS-1 with average output power $300 \mu \mathrm{W}$ and optical to $\mathrm{THz}$ conversion ratio $10^{-4}$. PTS-1 is ideal for scientific research applications due to radiation propagating through free space, flexible optical train and multipurpose software.

This development was supported by Russian Foundation for Assistance to Small Innovative Enterprises (FASIE), contract no. № $12234 p$ / 23287. 